\title{
INVESTIGATIONS OF GENERIC SELF DISASSEMBLY USING SHAPE MEMORY ALLOYS
}

\author{
J.D. Chiodo, E.H. Billett, D.J. Harrison and P. Harry \\ Cleaner Electronics Research \\ Brunel University, Runnymede Campus \\ Egham, Surrey, TW20 OJZ, UK
}

\begin{abstract}
Industrial recycling is a practice of growing importance while impending 'Take Back' European legislation and economic pressures are increasing. Landfill sites are becoming exhausted and the industry could benefit from a novel approach to recycling pre and post consumer waste. Cost constraints limit the number of different products that can be recycled. Recyclers are working on broadening the range of reusable components from this waste stream, but the proposed approach would significantly increase the volume of recyclable material used in manufacturing new products. This alternative could potentially reduce recycling cost per product in the event of mandatory recycling as a wide variety of consumer electronics could be actively or self disassembled on the same generic dismantling line. The use of Shape Memory Alloy (SMA) actuators in a wide variety of consumer electronic products in the same dismantling facility was tested. The candidate products had undergone a multi-stage hierarchical temperature regime on their macro and subassembly disassemblies and results reported. Two forms of SMA actuators were employed in the designs of actuators; these were one-way Nickel-Titanium (NiTi) and two-way Copper-Zinc-Aluminum (CuZnAl) actuators.
\end{abstract}

\section{INTRODUCTION}

A novel form of disassembly was tested on more than one type of product in the same dismantling facility. The internal designs of products with active or self disassembly in mind are altered to include Shape Memory Alloy (SMA) devices incorporated into their assembly. At the end of their useful consumer life upon collection, these products could enter the dismantling line at the recycler's facility, where the product's self-disassembly would be triggered by an appropriate variable temperature regime. This would be possible using products designed for 'Active Disassembly using Smart Materials' [1], the topic of earlier work.

With SMA actuators inside the candidate products, the products would enter a sequence of controlled temperature changes in which the SMA devices would be activated at appropriate stages. Active disassembly would then occur allowing different components to be sorted after, through conventional mechanical sorting technologies. This eliminates the need for product specific robotic disassembly, a research approach so far unable to provide an economic disassembly model. Active disassembly however, could provide an increase in the range of profitable recyclable products [2].
With this disassembly approach demonstrated in the earlier work, a larger variety of consumer products manufactured by various consumer electronics manufacturers could be recycled at the same facility.

Novel findings include multi stage generic disassembly through a temperature hierarchy $(70,85,100$ and 120 degrees Celsius) on product macro and sub assemblies with a variety of force provisions available from a number of NiTi and CuZnAl SMA actuators.

\section{BACKGROUND}

Currently, robotic disassembly is cost prohibitive. Hand disassembly is only economic for a small proportion of the input material [3]. In a global survey of manufacturers and recyclers, the majority of manufacturers felt that neither robotic nor hand disassembly was technically or economically feasible at the present time [4]. The active disassembly approach to recyclability and reuse of constituent components would widen the narrow band of economically feasible recyclable products.

Future trends in product design engineering point towards recycling as an integral part of the life cycle of electronic consumer products. Automation of dismantling the post consumer product is still seen as a product specific endeavor. As the amount and diversity of electronic products in our lives increase dramatically, current models of production and 'unproduction' seem outdated. This system would also enable manufacturers to separate toxic and dissimilar components and allow their reuse or safer disposal. This work, while focussed on electronic products, has the potential to lead to more generic applications in a wide range of industries.

This paper observes the initial results in the application of SMA devices in the active disassembly of assembled products. The smart materials considered in this study are alloys of Nickel-Titanium (NiTi) and Copper-Zinc-Aluminum ( $\mathrm{CuZnAl})$. In active disassembly, two distinct approaches can be taken when incorporated into existing product designs (retrofitted) or incorporated in the product during the design phase (design for active disassembly). In this initial investigation, the feasibility of retrofitting actuators to assembled products has been explored. The range of permissible ambient temperatures and the actuator transformation temperatures ( $\mathrm{Tg}$ ) will be considered. Future research will include design for active disassembly. The design of the actuators employed in these product trials is not 
to be regarded as optimal. The cost effectiveness of these components, the range of permissible ambient temperatures, and the actuator transformation temperatures [5] are considered key parameters to be optimized in future research.

\section{METHOD}

Prior to the generic disassembly experiments a further series of experiments concerned the disassembly of product housings, in which the metal assembly screws were removed to permit the required disassembly forces to approximate those, provided by the actuators. Details of snap fasteners included in these successful experiments described the parameters of force requirements and forces that needed to be surpassed [6]. All cases tested in these disassembly experiments proved successful and useful for this regime of generic disassembly tests.

Further preparations were made to accommodate the generic active disassembly experiments. As the NiTi alloys were superelastic in typical ambient temperatures [7] (or whilst in their $100 \%$ Martensite state [8]), it was necessary to anneal [9] the samples to rid them of any potential stresses experienced since manufacturing. Annealing and training [10] of NiTi SMA actuators are described in Table 1.

The NiTi SMA actuators were one-way [11] Shape memory effect (SME) but can be mechanically deformed [12] (whilst in $100 \%$ Martensite or below martensite finishing temperature (Mf) [13]) after their first and subsequent actuations. The CuZnAl SMA actuators did not require training as these were pre-trained off the shelf items. These actuators were of a helical design exhibiting two-way effect [14]. These devices did not require mechanical deformation after first and subsequent actuations. Table 1 details the annealing and training processes for the SMA actuators. Three designs of actuators were used, Fig 1 and Fig 2.

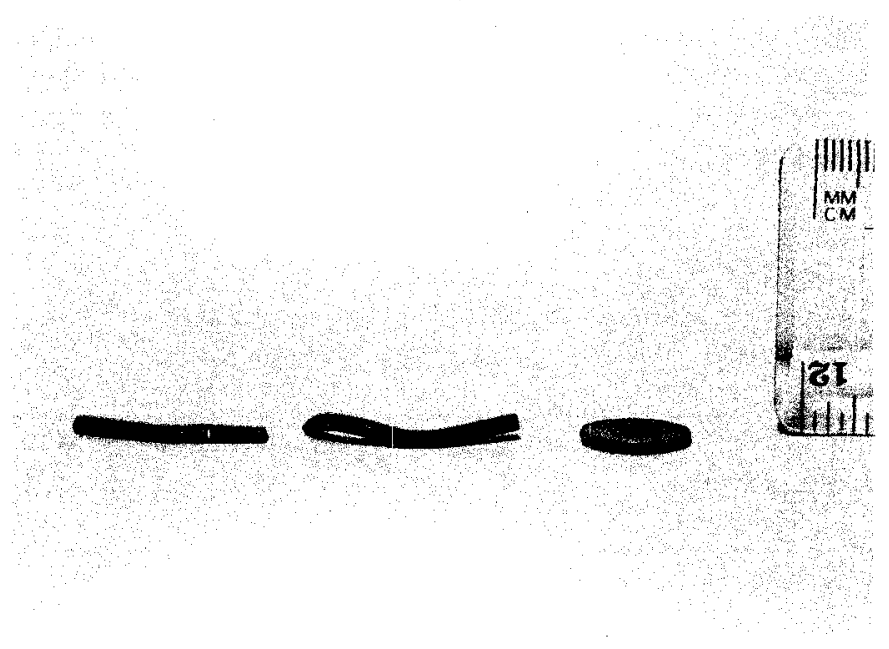

Fig. 1. SMA NiTi Rods and Disc were used in some of the candidate products, refer to Table 4. First, all NiTi 1-way actuators were trained and mechanically deformed, then inserted into the products for disassembly experiments.
TABLE 1

Annealing and Training of SMA Actuators

\begin{tabular}{|c|c|c|c|}
\hline Conditioning: & $\begin{array}{l}\text { Manipulat'n } \\
\text { /Positioning }\end{array}$ & $\begin{array}{l}\text { Temp. } \\
\text { Deg. (C.) }\end{array}$ & $\begin{array}{l}\text { Time } \\
(\min .)\end{array}$ \\
\hline \multirow{2}{*}{$\begin{array}{l}\text { Steps in } \\
\text { Annealing }\end{array}$} & n.a. & 700 & 45 \\
\hline & water bath & 20 & 1 \\
\hline \multicolumn{4}{|l|}{ Steps-Training } \\
\hline 1 Training & jig & $400-445$ & 45 \\
\hline 2 Quenching * & water bath & 20 & 1 \\
\hline $\begin{array}{l}3 \text { Mechanical } \\
\text { Deformation }\end{array}$ & manual** & $20,<$ As & $\begin{array}{l}\text { form } \\
\text { dependent }\end{array}$ \\
\hline 4 SME (Tg: As-f) & alloy specific & specific $* * *$ & $<0.5 \mathrm{sec}$ \\
\hline 5 Cooling & water bath & 20 & 1 \\
\hline 6 Cyclical Value & $\begin{array}{l}\text { mechanical } \\
\text { deform't'n \& S }\end{array}$ & $\begin{array}{l}\text { dependent } \\
\text { ME dependent }\end{array}$ & dependent \\
\hline \multicolumn{4}{|c|}{$\begin{array}{l}\text { Legend: } \\
\text { SMA = shape memory alloy } \\
\text { SME = shape memory effect } \\
\mathrm{Tg}=\text { Transformation temperature that is alloy specific } \\
\text { As-f = Ausenite starting to finishing temperature } \\
* \quad=\text { Imposing } 100 \% \text { Martensite structure (surpassing } \\
\\
\quad \text { Mf) from } 100 \% \text { Ausenite structure. } \\
=\text { Dependent on extent of required form change. In } \\
\quad \text { many cases, helical samples were jig formed and } \\
\quad \text { retrained } 5 \times \text { before conforming to desired shape. } \\
* * * \quad \text { The SME Tg depends on the SMA composition } \\
\text { (usual commercially availability }-40 \text { to }=140 \mathrm{C} \text { ). }\end{array}$} \\
\hline
\end{tabular}

All the SMA actuators would be in the martensite state and consequently a lower displacement shape while in a product in use at a typical ambient temperature range of approximately $-50-+90 \mathrm{C}$. As these SMA actuators are trained and mechanically deformed, they are ready for repeated SMEs. For this to happen, they must be heated to the Af temperatures, Table 3. Before incorporation into products, cycling through multiple SME trials successfully tested all the actuators. In the first series of active disassembly trials, the actuators were incorporated into product housings and were heated to exceed

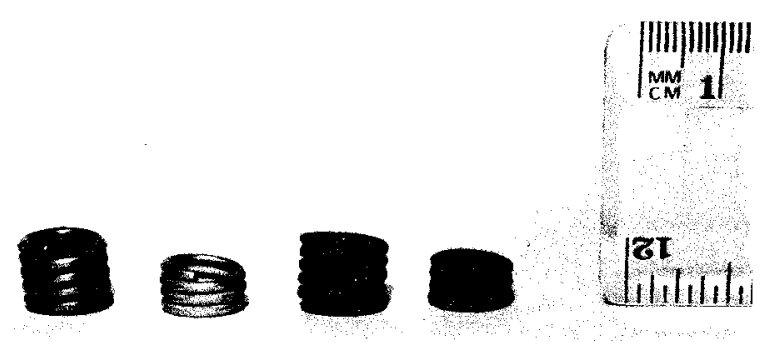

Fig. 2. 2-Way SMA CuZnAl helical coil actuators were used in some of the candidate products, Table 4. All CuZnAl actuators did not require training or mechanical deformation as they were pretrained. 
their Af temperatures. Following actuation the actuators returned in less than one second to their previously trained shapes, hence 'Shape Memory'. The SME is time independent but takes a noticeable time in the experiment, as heat must be conducted through the entire actuator for it to undergo SME. The temperature range required for a complete $\mathrm{SME}$ is termed as 'Austenite start to finish' (As-f). This temperature range is different than the temperature range required to induce a stable low temperature state or $100 \%$ Martensite state. The range at which this takes effect is known as Martensite start to finish (Ms-f). The difference between these two ranges is known as Hysteresis [15]. These actuators returned close to their trained shapes as dimensional changes were about $2 / 3$ rd to $4 / 5$ th of their original shapes after SME for the NiTi actuators. This characteristic and force return in SME are subject to the their trained shapes, cross section, force applied in mechanical deformation, composition of alloy and $\mathrm{Tg}$. The actuators can be subjected to repeated deformations and SME cycles. NiTi actuators were trained, mechanically deformed and tested prior to insertion into candidate products, Fig. 3 and Fig. 4.
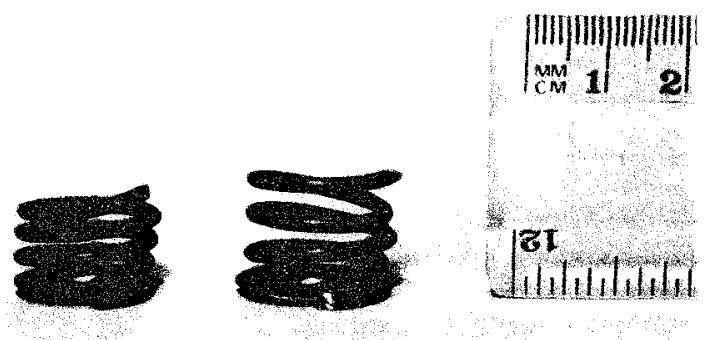

Fig. 3. SMA NiTi helical coils were used in some of the candidate products, Table 4. Displacement is shown prior to SME tests.
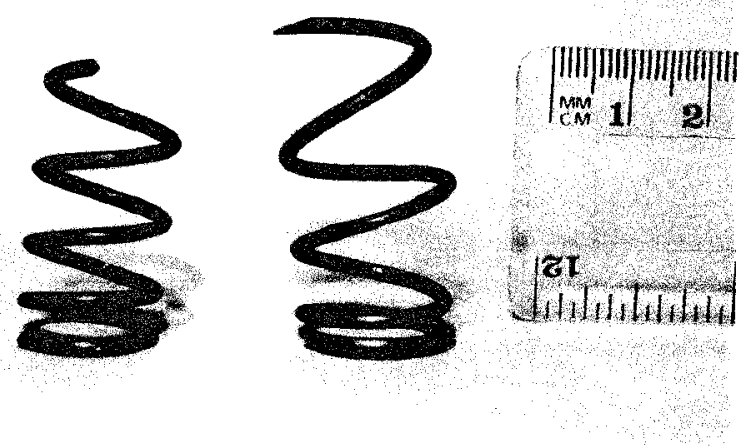

Fig. 4. Displacement after SME tests.
The generic disassembly experiments were conducted on a variety of products ranging from cell phones to a small electronic game. There were three different design styles in the fifty-five actuators employed in total. Before the experiments, all the products were disassembled manually without destruction to snap fasteners or product casings. The SMA actuators were then inserted into the macro and subassemblies of the test products. A small number of trials were performed previous to the experiments for appropriate placement, combinations of actuators in place and hierarchy of anticipated subassembly outcomes. This consisted of placing lower actuation temperature SMA actuators in the macro assemblies and higher temperature actuators in the subassemblies of the candidate products.

Upon insertions of actuators in the candidate products, the entire sample base was placed in a wooden and glass chamber. The chamber was then heated with air heating apparatus from room temperature quickly raising the average temperature from 20 to 75 degrees Celsius (C) in the first stage of the disassembly experiment with results reported.

The hierarchy in temperature regime continued from $70 \mathrm{C}$ to $115 \mathrm{C}$, see Table 2 . These temperatures were chosen to surpass the Af of actuators by at least $5 \mathrm{C}$. After 75 degrees $C$, vector heating was employed as difficulty was experienced with higher average temperatures in the chamber available.

General actuator placements for the corresponding hierarchical disassembly experiments are characterized for the candidate products, Table 4. Also noted are the Af temperatures of the actuators, their design types and particular product assembly separation required pertinent to the disassembly. Table 4, "Candidate Products" may have more than one of the same product and in some cases, the same type of product but by different manufacturers; this is for comparison reasons. These comparisons will be used in the investigation of design guidelines of generic disassembly using smart materials such as SMA employed in these experiments in future work. Disassembly hierarchies range from a one product one time self-disassembly with one actuator inside to a 3-time self-disassembly within one product housing four actuators. Table 3 is an actuator description of those employed in the experiments.

TABLE 2

Hierarchical Temperature Regime of SMA Actuator Employment by Stage

\begin{tabular}{|l|l|l|l|l|}
\hline $\begin{array}{l}\text { Actuator } \\
\text { Composition }>\end{array}$ & $\begin{array}{l}\text { Actual } \\
\text { Actuator } \\
\text { SME Af }\end{array}$ & NiTi & $\begin{array}{l}\text { NiTi \& } \\
\text { CuZnAl }\end{array}$ & NiTi \\
\hline Actuator Design> & & Rod & $\begin{array}{l}\text { Helical } \\
\text { (hel.) }\end{array}$ & Disc \\
\hline Stages: & & & & \\
\hline $1-70 \mathrm{C}$ & $60 \mathrm{C}$ & $\mathrm{x}$ & $\mathrm{x}$ & $\mathrm{x}$ \\
\hline $2-85 \mathrm{C}$ & $68-80 \mathrm{C}$ & & $\mathrm{x}$ & \\
\hline $3-100 \mathrm{C}$ & $80-90 \mathrm{C}$ & & $\mathrm{x}$ & \\
\hline $4-120 \mathrm{C}$ & $100 \mathrm{C}$ & & $\mathrm{x}$ & \\
\hline
\end{tabular}




\section{DESCRIPTIONS}

TABLE 3

Actuator Descriptions

\begin{tabular}{|c|c|c|c|c|c|c|c|c|c|c|c|c|}
\hline \begin{tabular}{|l|} 
A ctuator \\
Type \\
/ Composition \\
\end{tabular} & $\begin{array}{l}\text { As-Af } \\
\text { degrees }\end{array}$ & $\begin{array}{l}\text { Temp. } \\
\text { (C) }\end{array}$ & \begin{tabular}{|l} 
Pre \\
SME \\
Height
\end{tabular} & \begin{tabular}{|l} 
Post \\
SME \\
Height
\end{tabular} & \begin{tabular}{|l} 
Force \\
Provision \\
$(\mathrm{N})$
\end{tabular} & $\begin{array}{l}\text { Moment } \\
(N M) \text { or } \\
\text { Deflext'n }\end{array}$ & $\begin{array}{l}\text { Required } \\
\text { A mbient } \\
\text { Temp. }\end{array}$ & $\begin{array}{l}\text { Mass } \\
\text { Actuators } \\
(\mathrm{gr})\end{array}$ & $\begin{array}{l}\text { O.D. } \\
\text { Pre } \\
\text { SM E }\end{array}$ & $\begin{array}{l}\text { I.D. } \\
\text { Pre } \\
\text { SME }\end{array}$ & $\begin{array}{l}\text { O.D. } \\
\text { Post } \\
\text { SM E }\end{array}$ & $\begin{array}{l}\text { I.D. } \\
\text { Post } \\
\text { SM E }\end{array}$ \\
\hline disc NiTi & 60 & 70 & 3 & 1.2 & $>2200$ & 1.8 & 70 & 0.96 & 13 & n.a. & n.a. & n.a. \\
\hline $\operatorname{rod} \mathbf{N i T i}-1$ & 52 & 60 & 2.3 & 6 & 63.7 & $0.828 \mathrm{NM}$ & 60 & 0.71 & 2.2 & n.a. & n.a. & n.a. \\
\hline $\operatorname{rod} \mathrm{NiTi}-2$ & 52 & 60 & 2.3 & 6 & 63.7 & $0.828 \mathrm{NM}$ & 60 & 0.57 & 2.2 & n.a. & n.a. & n.a. \\
\hline helical coil NiTi: & & & & & & & & \multicolumn{4}{|c|}{ values below are approx. } & \\
\hline $\begin{array}{r}\text { medium - 1 } \\
\end{array}$ & 45 & 60 & 14 & 30 & $>500$ & 16 & 60 & 4.93 & 17.8 & 14 & 18 & 14 \\
\hline medium - 2 & 45 & $60-96$ & 29.22 & 42 & $>500$ & 12.78 & 100 & 5.35 & 17.2 & 12.75 & 21.3 & 15.4 \\
\hline large - 1 & 95 & 100 & 31 & 44.8 & $>500$ & 13.8 & 120 & 9.02 & 19.74 & 14.32 & 22.6 & 19.66 \\
\hline large - 2 & 95 & 100 & 23.5 & 72 & $>500$ & 48.5 & 120 & 6.17 & 18 & 13 & 19.35 & 13.5 \\
\hline helical coil CuZnAl: & & & & & & & & \multicolumn{4}{|c|}{ values below are approx. } & \\
\hline small coated & $62-77$ & $72-87$ & 6 & $11-14$ & $3-6.25$ & $5 .-8$. & 85 & $1.4-1.5$ & 10.07 & 7.48 & 10.1 & 7.5 \\
\hline small uncoated & $63-68$ & $68-77$ & 6 & $12-13$ & $3-6.25$ & $6 .-7$ & 85 & $1.46-1.48$ & 10.06 & 7.5 & 10.1 & 7.5 \\
\hline medium coated & $62-72$ & $70-77$ & 11 & $18-22$. & $12-13.5$ & 7. -11. & 85 & $2.95-3.12$ & 11.15 & 7.7 & 11.2 & 7.7 \\
\hline medium uncoated & $73-75$ & $85-90$ & 10.1 & 17-19. & $12-13.5$ & $6.9-8.9$ & 100 & $2.75-2.84$ & 10 & 7.5 & 10 & 7.5 \\
\hline
\end{tabular}

\section{RESULTS}

TABLE 4

Hierarchical Actuator Placement by Product and

Results of Generic Disassembly Experiments

\begin{tabular}{|c|c|c|c|c|c|c|c|}
\hline \multirow[b]{2}{*}{ Candidate Products: } & \multicolumn{5}{|c|}{ Hierarchical Actuator Placement by Product: } & \multicolumn{2}{|l|}{ Results: } \\
\hline & Placement & $\begin{array}{l}\text { Af (C) at } \\
\text { Disassembly }\end{array}$ & $\begin{array}{l}\text { Actuator } \\
\text { Type }\end{array}$ & $\begin{array}{l}\text { Hierarchy } \\
\text { Within } \\
\text { Product? }\end{array}$ & $\begin{array}{l}\text { Disassembly } \\
\text { Technique }\end{array}$ & $\begin{array}{l}\text { Stages } \\
\text { of } \\
\text { Disassembly }\end{array}$ & $\begin{array}{l}\text { Fully } \\
\text { Successful } \\
\text { Disassembly? }\end{array}$ \\
\hline A4 17" Monitor CRT & \multicolumn{2}{|c|}{ attempted at glass seam } & n.a. & n.a. & failed & n.a. & \begin{tabular}{|c} 
n.a. \\
\end{tabular} \\
\hline PC Keyboard & \multicolumn{2}{|c|}{ attempted on macro assembly } & n.a. & n.a. & failed & n.a. & n.a. \\
\hline Motorolla Cell Phone - 1 & bottom end & 60 & $\operatorname{rod~NiTi}$ & No & Snap fit expansion & 1 & no \\
\hline Motorolla Cell Phone - 2 & middle & 60 & $\operatorname{rod~NiTi}$ & $"$ & (1) & 1 & no \\
\hline Motorolla Cell Phone - 3 & \multicolumn{2}{|c|}{ attempts on macro assembly } & n.a. & n.a. & failed & n.a. & n.a. \\
\hline Motorolla Cell Phone - 4 & \multicolumn{2}{|c|}{ attempts on sub assembly } & n.a. & n.a. & failed & n.a. & n.a. \\
\hline PC Mouse & $\begin{array}{l}\text { center rear } \\
\text { keys front }\end{array}$ & $\begin{array}{c}60 \\
73,73 \\
\end{array}$ & $\begin{array}{l}\text { helical coil NiTi } \\
\text { helical coil CuZnAl }\end{array}$ & $\begin{array}{c}2 \text { stage } \\
"\end{array}$ & $\begin{array}{c}\text { Snap fit expansion } \\
"\end{array}$ & $\begin{array}{l}1 \\
2\end{array}$ & $\begin{array}{l}\text { yes } \\
\text { yes }\end{array}$ \\
\hline Sharp Calculator & $\begin{array}{l}\text { top end } \\
\text { middle }\end{array}$ & $\begin{array}{c}60 \\
85,85 \\
\end{array}$ & $\begin{array}{l}\text { helical coil NiTi } \\
\text { helical coil } \mathrm{CuZnAl}\end{array}$ & $\begin{array}{c}2 \text { stage } \\
"\end{array}$ & $\begin{array}{c}\text { Snap fit expansion } \\
"\end{array}$ & $\begin{array}{l}1 \\
2 \\
\end{array}$ & $\begin{array}{l}\text { yes } \\
\text { yes }\end{array}$ \\
\hline Apple Adj. Keyboard & front end & 70 & disc NiTi & No & Snap fit expansion & 1 & no \\
\hline Battery Charger & $\begin{array}{l}\text { bottom end } \\
\text { middle }\end{array}$ & $\begin{array}{c}68,70 \\
100 \\
\end{array}$ & $\begin{array}{l}\begin{array}{l}\text { helical coil CuZnAl } \\
\text { helical coil NiTi }\end{array} \\
\end{array}$ & $\begin{array}{c}2 \text { stage } \\
"\end{array}$ & Compression fit expansion & $\begin{array}{l}2 \\
4 \\
\end{array}$ & $\begin{array}{l}\text { no } \\
\text { no }\end{array}$ \\
\hline Kodak S.U.Camera-1 & $\begin{array}{l}\text { top middle } \\
\text { side }\end{array}$ & $\begin{array}{l}70 \\
70\end{array}$ & $\begin{array}{l}\text { helical coil } \mathrm{CuZnAl} \\
\text { helical coil } \mathrm{CuZnAl}\end{array}$ & $\begin{array}{c}2 \text { stage } \\
"\end{array}$ & $\begin{array}{c}\text { Snap fit expansion } \\
"\end{array}$ & $\begin{array}{l}2 \\
2 \\
\end{array}$ & $\begin{array}{l}\text { yes } \\
\text { yes }\end{array}$ \\
\hline Kodak S.U.Camera-2 & $\begin{array}{l}\text { center bottom } \\
\text { top right } \\
\text { top middle }\end{array}$ & $\begin{array}{c}70 \\
72,72 \\
73\end{array}$ & $\begin{array}{l}\text { helical coil } \mathrm{CuZnAl} \\
\text { helical coil } \mathrm{CuZnAl} \\
\text { helical coil } \mathrm{CuZnAl}\end{array}$ & $\begin{array}{c}3 \text { stage } \\
" \\
"\end{array}$ & $\begin{array}{c}\text { Snap fit expansion } \\
" \\
\end{array}$ & $\begin{array}{c}2 \\
2 \& 2 \\
2 \\
\end{array}$ & $\begin{array}{l}\text { yes } \\
\text { yes } \\
\text { yes }\end{array}$ \\
\hline Sung PC Mouse-1 & $\begin{array}{l}\text { key seats } \\
\text { bottom of PCB }\end{array}$ & $\begin{array}{l}71,72 \\
85,85\end{array}$ & $\begin{array}{l}\text { helical coil } \mathrm{CuZnAl} \\
\text { helical coil } \mathrm{CuZnAl}\end{array}$ & $\begin{array}{c}2 \text { stage } \\
n\end{array}$ & $\begin{array}{l}\text { Snap fit expansion } \\
\text { Compression fit expansion }\end{array}$ & $\begin{array}{l}2 \\
3 \\
\end{array}$ & $\begin{array}{l}\text { yes } \\
\text { yes }\end{array}$ \\
\hline Sung PC Mouse-2 & $\begin{array}{l}\text { bottom of PCB } \\
\text { key seats }\end{array}$ & $\begin{array}{l}78,74 \\
80,85 \\
\end{array}$ & $\begin{array}{l}\text { helical coil } \mathrm{CuZnAl} \\
\text { helical coil } \mathrm{CuZnAl}\end{array}$ & $\begin{array}{c}2 \text { stage } \\
"\end{array}$ & $\begin{array}{l}\text { Compression fit expansion } \\
\text { Snap fit expansion }\end{array}$ & $\begin{array}{l}2 \\
3 \\
\end{array}$ & $\begin{array}{l}\text { yes } \\
\text { yes }\end{array}$ \\
\hline Brats Calculator Round & end & 75,77 & helical coil CuZnAl & No & Snap fit expansion & 2 & yes \\
\hline Royal Personal Org. & center & 77,77 & helical coil CuZnAl & No & Snap fit expansion & 2 & yes \\
\hline TI Calculator & end & 76,75 & helical coil $\mathrm{CuZnAl}$ & No & Snap fit expansion & 2 & yes \\
\hline Brats Calculator Square & middle & 80 & helical coil CuZnAl & No & Snap fit expansion & 2 & yes \\
\hline Canon Calculator & ends diag. & 80,80 & helical coil CuZnAl & No & Snap fit expansion & 2 & yes \\
\hline Electronic Game & middle & 90,90 & helical coil CuZnAl & No & Compression fit expansion & 3 & yes \\
\hline Adj. Number Keypad & center rear & 100 & helical coil NiTi & No & Snap fit expansion & 4 & no \\
\hline Legend: & n.a. $=$ not applic & able & Degrees $(\mathrm{C})=$ Celsiu & & & & \\
\hline
\end{tabular}




\section{CONCLUSIONS}

Most of the candidate products proved successful in the temperature/hierarchical generic disassembly experiments. From the beginning, only the A4 (17") CRT monitor, one PC keyboard and two of the four cell phones were not fit for disassembly as actuator placement proved difficult in the time allotted. Of the fifty-five actuators used, all provided SME successfully with some of the 2-way CuZnAl actuators over stressed and thus, not able to provide SME to the designed specifications repeatedly, fig. 8 . Of the twenty-one products chosen, four were unable to be tested. Of the remaining seventeen, twelve products successfully dismantled with nineteen SME disassembly occurrences since some of the products were of a multi-stage nature. Of the five products unsuccessful, six failures occurred in total. Seven of the products were multi-stage and one, the Kodak S.U.Camera-2, was a 3-stage all within the temperature regime "Stage of Disassembly 2". The SMA devices in this application successfully dismantled the camera at 70,72 and 73 degrees C. This camera's result exhibits some accuracy potential within an active or self-disassembly system as a generic process. Table 5 describes the nature of experiments throughout the four stages of the hierarchical disassembly/temperature regimes.

The experiments made it clear that exposure to ambient temperature was insufficient. This was especially the case in the unsuccessful experiments, Fig 6. As SME is temperature dependent, it is crucial that allowances be made in the product sub and macro assemblies for ambient temperatures to affect the SMA devices before destroying the product, Fig 5 .

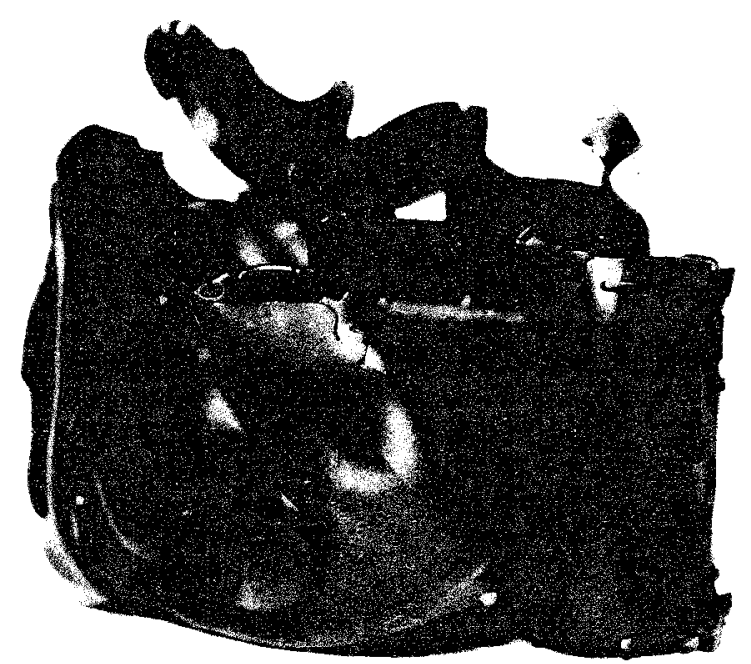

Fig. 5. CuZnAl actuators were placed inside the camera. The disassembly was successful (Stage 2) however; the product was not removed until after the full batch of products were exposed past the Stage 4 temperature regime.

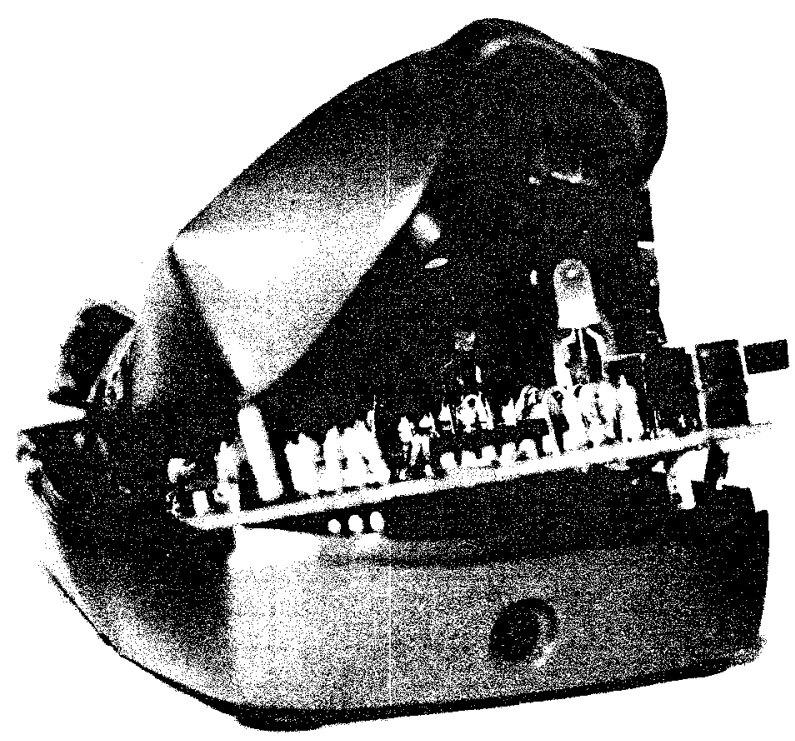

Fig. 6. NiTi actuators were placed inside the battery charger for disassembly (Stages 2 \& 4), Table 4. The disassembly was unsuccessful, but destroyed the casing. The product still required forceful prying to dismantle.

Product design must include some changes to the housing of the intended products if active or self-disassembly were to take place otherwise, significant damage can result, Fig. 7 . This adjustable keyboard was significantly destroyed as the $\mathrm{NiTi}$ actuator was unable to receive a significant increase in ambient temperature to react before the polymer casing began to give way, not allowing a clean break apart at the snap fastening.

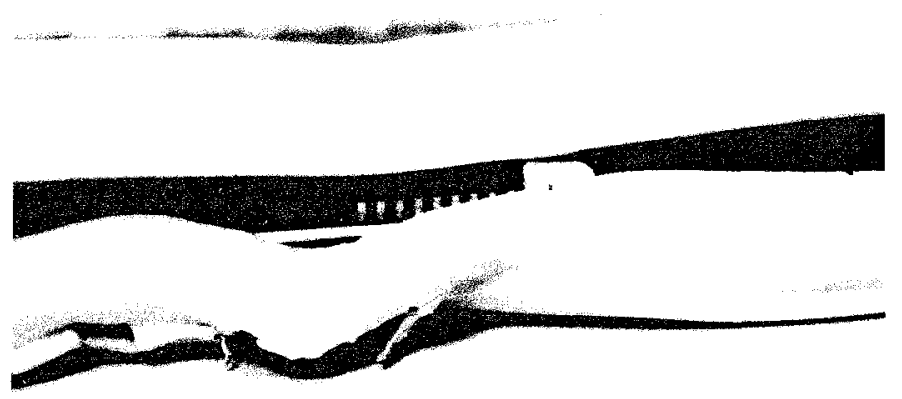

Fig. 7. A NiTi actuator was placed inside the adjustable keyboard for disassembly at Stage 1, a low temperature actuation, Table 4. The disassembly was unsuccessful. Whilst the polymer housing was broken, the product still required forceful prying to dismantle. 


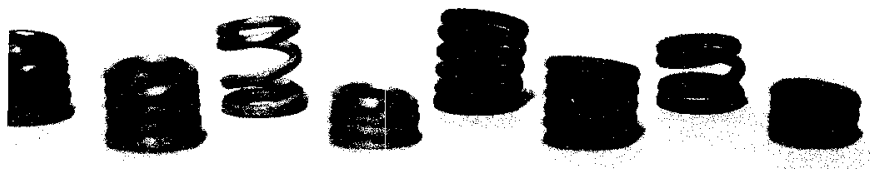

Fig. 8. CuZnAl actuators exposed past their Af for extended periods of time no longer fit for repeated SME.

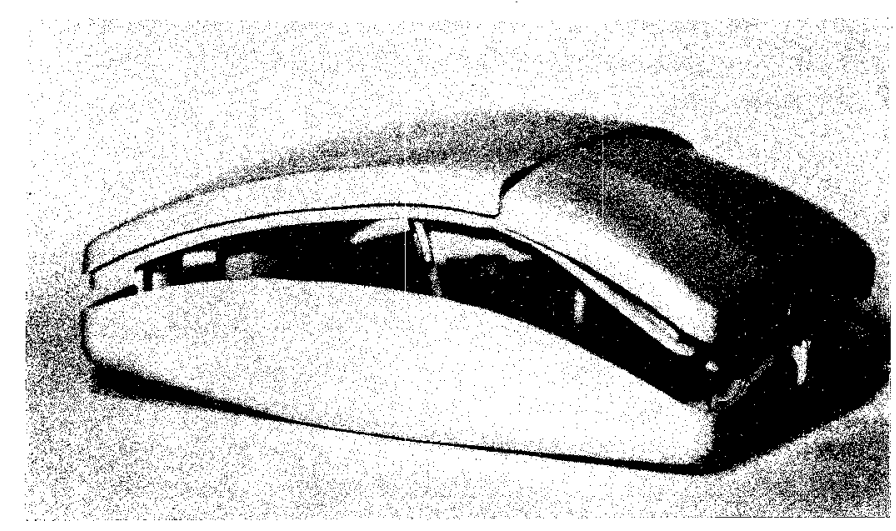

Fig. 9. SMA NiTi and CuZnAl actuators were used in the 2 Stage disassembly of this successfully disassembled $P C$ mouse. The cord was easily removed and all internal components remain intact.

Earlier work has found similar requirements in design changes necessary for self-disassembling products [16]. Other observations suggest SMA devices should not be exposed to higher temperatures than their Af for an extended period of time as this affects cyclical values, Fig. 8. Future work will address these and other issues. Most of the products disassembled in this study proved successful, Fig. 9.

The overall research is part of on going step change studies [17] attempting to tackle environmental impact reduction in consumer electronics in part through diversified needs scenarios $[18,19]$. Preliminary findings were based on the study at Brunel University [20].

\section{ACKNOWLEDGMENT}

Paul Harry thanks for help in data collection at Brunel University UK. Teresa O'Toole thanks for the use of the lab, also for data collection at Durham College, Oshawa ON Canada. MANN Recycling (Eric Tickner) thanks for the facility observations and cell phones. Paul Simpson thanks for the use of testing and observation equipment at Brunel.
[1] E.H. Billett, Active Disassembly using SMART Materials (ADSM), unconventional ideas EPSRC research grant, Brunel University, Runnymede, Surrey, UK, 28 April 1996 to 28 April 1997.

[2] C.B. Boks, Delft University of Technology, from conversation, The Netherlands, 12 February 1997.

[3] MANN Recyclers: E. Tickner (Special Projects Manager), A. Thomas (Senior Production Engineer). From conversation, Ross on Wye, UK, 16 April 1997.

[4] C.B. Boks, E. Tempelman, "Future disassembly and recycling technology for the electronics and automotive industry," Delphi Study Report - K370, Delft University of Technology, The Netherlands, April 1997, pp. 10.

[5] R.G. Gilbertson, Muscle Wires Project Book. Mondo-tronics, Inc., San Anselmo, CA., 1994, pp. $2-7$.

[6] J.D. Chiodo, J.D. Chiodo, T. Anson, E.H. Billett, D.J. Harrison and M. Perkins, "Eco-design for active disassembly using smart materials," Shape Memory and Superelastic Technologies (SMST) conference, Asilomar Conference Center, Pacific Grove, CA., USA., 2-6 March 1997.

[7] R.G. Gilbertson, Muscle Wires Project Book. Mondo-tronics, Inc., San Anselmo, CA., 1994, pp. 2-7.

[8] R.A. Higgins, Engineering Metallurgy. Edward Arnold, London, 1983, pp. 157.

[9] R.G. Gilbertson, Muscle Wires Project Book. Mondo-tronics, Inc., San Anselmo, CA., 1994, pp. 2-4.

[10] D.E. Hodgson, Ming H. Wu and Robert J. Biermann. (1997). Shape Memory Alloys, SMA Inc. http://www.smainc.com/SMAPaper.html

[11] P. Tautzenberger, Engineering Aspects of Shape Memory Alloys. (P. Tautzenberger, D. Stockel and C.M.Wayman, ed.), Butterworth-Heinemann, New York, 1990, pp. 208.

[12] R.A. Higgins, Engineering Metallurgy. Edward Arnold, London, 1983, pp. 90.

[13] R.G. Gilbertson, Muscle Wires Project Book. Mondo-tronics, Inc., San Anselmo, CA., 1994, pp. 2-7.

[14] R.F. Gordon, Engineering Aspects of Shape Memory Alloys. (T.W Duerig, K.N. Melton, D. Stockel and C.M. Wayman, ed.), Butterworth-Heinemann, New York, 1990, pp. 245.

[15] R.G. Gilbertson, Muscle Wires Project Book. Mondo-tronics, Inc., San Anselmo, CA., 1994, pp. 2-6.

[16] J.D. Chiodo and E.H. Billett, "Preliminary outline guidelines for active disassembly," Product Design Education 1997 PDE'97, Conference, July 1997. Brunel University, Runnymede, Surrey, UK.

[17] J.D. Chiodo, P.J. Simpson and E.H. Billett, "Socially responsible design eco-needs scenario comparison," Product Design Education 1997 PDE'97, Conference, July 1997. Brunel University, Runnymede, Surrey, UK.

[18] ibid.

[19] J.D. Chiodo, B.J. Ramsey and P.J. Simpson, "The development of a step change design approach to reduce environmental impact through provision of alternative processes and scenarios for industrial designers," ICSID'97 The Humane Village Congress, 1997, Conference, August 1997. The Design Exchange, Toronto, ON, Canada. In press

[20]J.D. Chiodo and E.H. Billett, "Active disassemblyinvestigation," Journal of Sustainable Design, Refereed Journal, Surrey, UK, 1988. In press. 